\title{
Periodic Attacks of Lethargy in a Baby with Ammonia Intoxication Due to a Congenital Defect in Ureogenesis ${ }^{\star}$
}

\author{
L. M. CORBEEL, J. P. COLOMBO, M. VAN SANDE, and A. WEBER \\ From the Department of Paediatrics, University of Louvain, Belgium; The Department of Paediatrics, University of Berne, \\ Switzerland; and the Department of Neurology, Institute Bunge, Antwerp, Belgium
}

Hyperammonaemia due to a deficient urea cycle (Fig. 1) has been attributed to at least four distinct enzyme defects: (1) hyperammonaemia due to a defect of carbamyl-phosphate synthetase ini the liver (Freeman et al., 1964); (2) hyperammonaemia due to a defect of ornithine carbamyl transferase with or without defect of carbamyl phosphate synthetase in the liver (Russell et al., 1962; Hopkins et al., 1969; Levin et al., 1969a; Levin et al., 1969b); (3) citrullinaemia due to a defect of argininosuccinic acid synthetase in the liver (McMurray et al., 1964) and in fibroblast cultures (Tedesco and Mellman, 1967); and

Received April 17, 1969.

* Presented in part to the Sixth Annual Symposium on Inborn Errors of Metabolism, Zürich, Switzerland, June 1968.
(4) argininosuccinic aciduria due to a defect of argininosuccinase in the liver (Levin, 1965), in the red cells (Tomlinson and Westall, 1964), or in the brain (Hooft, Carton, and De Schrijver, 1968).

The present case concerns a patient with attacks of lethargy due to ammonia intoxication and in whom the main defect in ureogenesis was a disturbance of ornithine carbamyl transferase, and secondarily of carbamyl phosphate synthetase.

\section{Methods}

Blood for ammonia determination was allowed to flow from a punctured vein immediately into a glass-stoppered flask. Ammonia determinations were performed in triplicate using the microdiffusion method of Seligson and Hirahara (1957). Amino acids were analysed

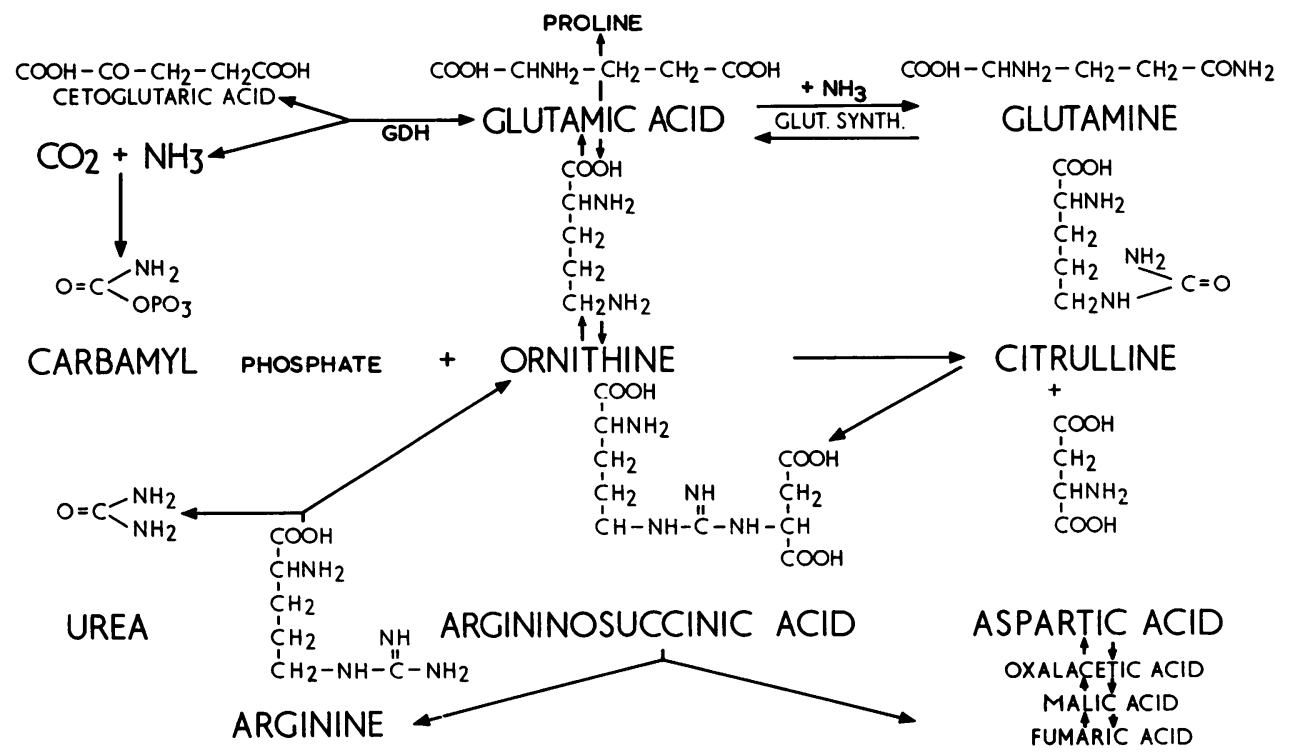

FIG. 1.-Urea cycle. 
with the Technicon amino acid analyser using the technique of Efron (1965). Plasma was deproteinized with solid sulphosalicyclic acid. Normal values of plasma amino acids were determined in 10 children of the same age as the patient. Orotic acid was determined in the urine by paper chromatography using a mixture of propanol, formic acid, water (7:1:2:) as a solvent. The spots were visualized in ultraviolet light and coloured with bromphenol blue according to the technique described by Thomson (1960). Quantitative orotic acid analyses were performed according to the technique of Rogers and Porter (1968).

The following assays of the urea cycle enzymes were modified from the methods of Brown and Cohen (1959). Carbamylphosphate synthetase (Colombo and Richterich, 1968); argininosuccinate cleavage enzyme (Colombo et al., 1967a); arginase (Colombo et al. 1967a); ornithine carbamyl transferase was determined following the method of Weber (1963), aspartate aminotransferase modified from Karmen (Richterich, 1969) and alanine aminotransferase modified from Wroblewsky and La Due (Richterich, 1969); glutamate dehydrogenase after Richterich (1969).

\section{Case Report}

The patient was the first child of healthy, unrelated parents; the antenatal and neonatal history was normal. Birthweight was $3.5 \mathrm{~kg}$. She started vomiting at the age of 14 days; she was admitted to hospital at the age of 1 month after her mother found she was unable to wake her in the morning. She remained in a coma for 48 hours, and extensive investigations failed to reveal the cause. The only abnormal findings were a diffuse slow wave pattern on EEG and a slight increase in urinary amino acids on paper chromatography; blood amino acids on paper chromatography were interpreted as normal. The child was treated with intravenous fluids and was discharged without a diagnosis
14 days later. After this initial episode, her development was slow. At the age of 12 months her weight was $10 \mathrm{~kg}$. She was unable to sit alone. Vomiting recurred repeatedly; during the episodes of vomiting she became sleepy and refused any food for 12-14 hours, but then recovered spontaneously if the mother offered water liberally. There was no diarrhoea. Vomiting increased in frequency after the age of 1 year; and she was referred at the age of $\mathbf{1 8}$ months for failure to thrive, along with mild mental retardation.

At the time of admission she was fairly well nourished, weighing $10 \mathrm{~kg}$., the length was $78 \mathrm{~cm}$., corresponding to the 25th centile; she was unable to stand alone and was hypotonic. There was slight microcephaly, head circumference $43 \mathrm{~cm}$. She was quite responsive to her surroundings.

Radiological examination of the gastro-intestinal tract was normal, as was the bone age.

During the first week in hospital vomiting occurred several times a day, but the weight remained unchanged. Analyses of blood, urine, and CSF were normal. The only abnormal finding was an increase in blogd transaminases: GOT 172 IU (normal for age: 7-35), GPT 131 IU (normal for age: 6-32). Total protein, electrophoresis, and immunoelectrophoresis were normal.

On the 8th day after admission vomiting increased suddenly, she lost $500 \mathrm{~g}$. within 24 hours, and went into a coma. The liver, previously of normal size, was slightly enlarged. Blood $\mathrm{pH}$ and plasma electrolytes were normal. Blood ammonia analyses performed for the first time gave very high values: $300 \mu \mathrm{g} . / 100 \mathrm{ml}$. (normal range up to $120 \mu \mathrm{g} . / 100 \mathrm{ml}$.). Blood urea was only $26 \mathrm{mg} . / 100 \mathrm{ml}$. Plasma bilirubin and flocculation test were normal, but the transaminases remained high: GOT $176 \mathrm{IU}$, GPT $200 \mathrm{IU}$, aldolase 6.5 IU (normal for age: 1·5-5), LDH 669 IU (normal for age : $340-600$ ).

At that time the chromatogram of the plasma amino acid (Fig. 2) showed that there was almost no arginine

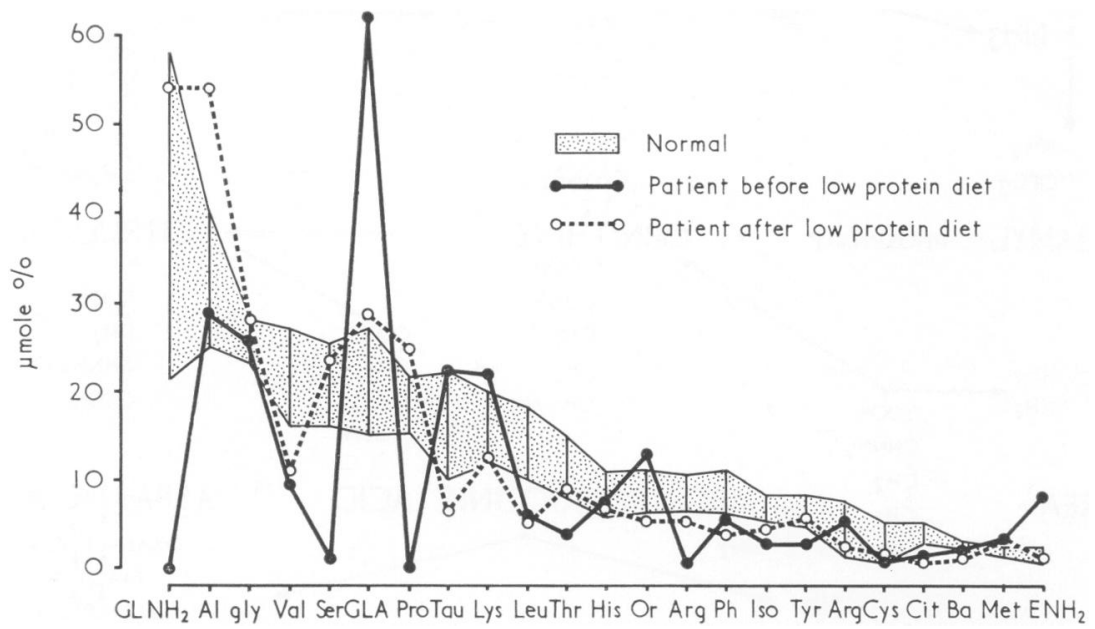

FIG. 2.-Plasma aminogram of the patient before and after low protein diet compared to the normal. 
$(0.4 \mu \mathrm{mole} / 100 \mathrm{ml}$.); citrulline was in the lower range (1.9 $\mu$ mole $/ 100 \mathrm{ml}$.), ornithine was increased $(13.4$ $\mu$ mole $/ 100 \mathrm{ml}$.$) . Glutamine { }^{\star}$ and proline were not measurable; serine, leucine, isoleucine, valine, phenylalanine, tyrosine, and threonine were decreased. Glutamic acid was increased (64 $\mu$ mole $/ 100 \mathrm{ml}$.), as was ethanolamine. Glycine, alanine, aspartic acid, and lysine were in the normal range.

The quantitative chromatography of amino acids in urine showed a very low excretion of arginine and ornithine, and the other amino acids were also mainly on the lower level of the normal range, as taken from the measurements of Vis (1963).

Amino acid analyses of CSF 5 days after the first plasma chromatogram (Fig. 3) showed an increase in glutamine and glutamic acid, a decrease in arginine, and lower or normal levels of ornithine and citrulline.

In this first episode of coma, the child was treated with fluids intravenously for 4 days. Consciousness returned after 24 hours, when the blood ammonia had dropped to $120 \mu \mathrm{g} . / 100 \mathrm{ml}$. She was then put on a low protein diet of $0.5 \mathrm{~g}$. protein $/ \mathrm{kg}$. per day. After only 10 days on that diet the amino acid chromatogram of the plasma was quite different. Glutamic acid was in the normal range, but glutamine had increased to $76 \cdot 3 \mu \mathrm{mole} /$ $100 \mathrm{ml}$.; proline and serine were present in normal amounts, but arginine and citrulline remained low (Fig. 2). With this diet, which was continued during the next 3 months, vomiting ceased completely, and she gained $1 \mathrm{~kg}$. weight within a month. The transaminases became normal and postprandial blood ammonia remained below $100 \mu \mathrm{g} . / 100 \mathrm{ml}$.

After 3 months the protein content of the diet was increased to $1 \mathrm{~g} . / \mathrm{kg}$. per day. This was well tolerated, and during the next 6 months, the weight increased by

\footnotetext{
* The absence of glutamine was presumably due to technical
} error.
$3 \mathrm{~kg}$. and the length by $6 \mathrm{~cm}$. Mental retardation, however, was not improved. After this she was again put on a high protein diet of $3 \mathrm{~g} . / \mathrm{kg}$. per day for 3 days, but on the first day of this diet she started vomiting and on the third day she became comatose, with the blood ammonia having risen to $232 \mu \mathrm{g} . / 100 \mathrm{ml}$. Plasma urea did not increase (Table I).

\section{Special Studies}

Histology of liver biopsy. A surgical liver biopsy was performed 19 days after an episode of coma. The general architecture of this liver biopsy was normal, the hepatocytes were swollen and showed some fine fatty degeneration; special stains for reticulin and with PAS gave normal pictures.

Enzyme content of the liver biopsy. The figures are shown in Table II. Of the enzymes of the urea cycle, ornithine carbamyl transferase was decreased to $35 \%$ of the lowest control value and carbamyl phosphate synthetase to $50 \%$ of the lowest control value. The argininosuccinate cleavage enzyme and arginase were within the range of the control values, as were glutamate dehydrogenase and alanine aminotransferase, whereas aspartate aminotransferase was increased.

Loading tests. These loading tests were performed in the morning after an 8-hour fast. (a) Ammonium chloride was infused intravenously within 20 minutes in an amount of $90 \mathrm{mg}$. $/ \mathrm{kg}$. for the first test, one month after an episode of coma. A second test was performed using $40 \mathrm{mg}$. $/ \mathrm{kg}$. after 6 months on a low protein diet. (b) L-arginine $150-200 \mathrm{mg} . / \mathrm{kg}$. was infused intravenously slowly over 4 hours in a $5 \%$ solution of sorbitol. (c) L-lysine $100 \mathrm{mg} . / \mathrm{kg}$. was infused intravenously over 30 minutes. (d) DL-ornithine was given by gavage in a dosage of $100 \mathrm{mg}$. $/ \mathrm{kg}$.

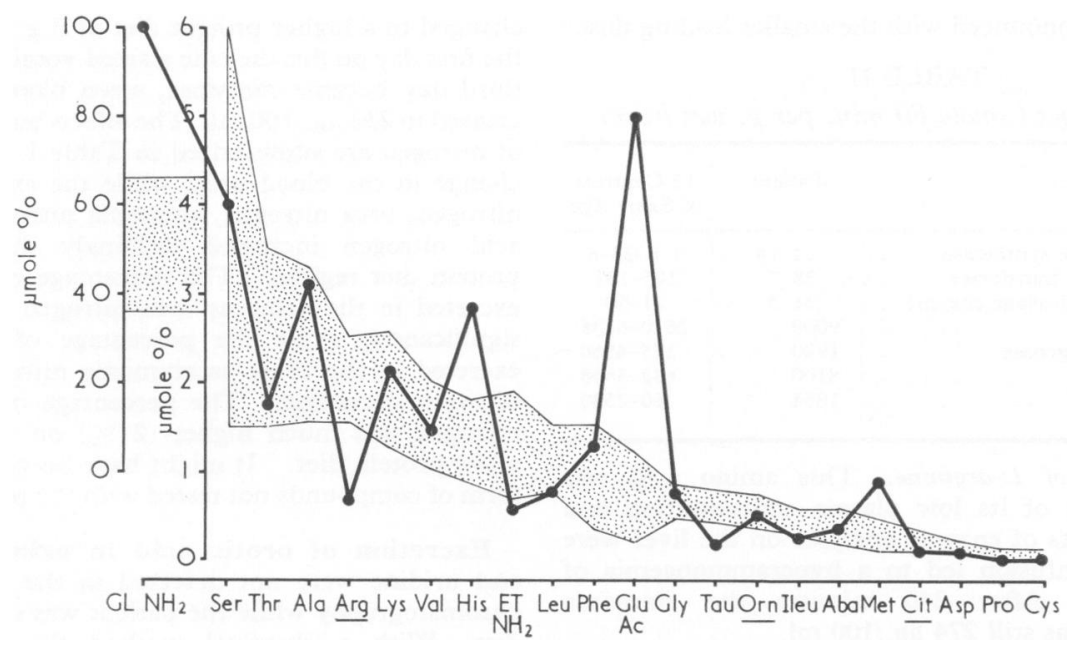

FIG. 3.-CSF aminogram of the patient compared with the normal (shaded area). 
TABLE I

Effects of Low Protein Diet of $1 \mathrm{~g} . / \mathrm{kg}$. per day, and High Protein of $3 \mathrm{~g} . / \mathrm{kg}$. per day on Nitrogen Metabolism*

\begin{tabular}{|c|c|c|c|c|c|c|c|c|}
\hline Day & 1 & 2 & 3 & Mean & 4 & 5 & 6 & Mean \\
\hline Protein intake (g./kg. per day) $t$ & 1 & 1 & 1 & 1 & 3 & 3 & 3 & 3 \\
\hline $\begin{array}{l}\text { Blood: Urea (mg./100 ml.) } \\
\mathrm{NH}_{3}(\mu \mathrm{g} . / 100 \mathrm{ml} .) \\
\text { Amino acids (mg./100 ml.) }\end{array}$ & 21 & $\begin{array}{l}25 \\
74 \\
\mathbf{4 4}\end{array}$ & 24 & 23 & 23 & 25 & $\begin{array}{l}24 \\
232 \\
38 \cdot 9\end{array}$ & 24 \\
\hline $\begin{array}{l}\text { Urine (ml./24 hr.) } \\
\text { Total nitrogen (mg./24 hr.) }\end{array}$ & $\begin{array}{r}62 \\
495\end{array}$ & $\begin{array}{r}50 \\
380\end{array}$ & $\begin{array}{r}51 \\
445\end{array}$ & 440 & $\begin{array}{l}160 \\
960\end{array}$ & $\begin{array}{r}150 \\
2220\end{array}$ & $\begin{array}{r}45 / 10 \mathrm{hr} \\
455 / 10 \mathrm{hr}\end{array}$ & 1424 \\
\hline $\begin{array}{l}\text { Urea } \mathrm{N}_{2} \text { (mg./24 hr.) } \\
\% \text { of total urea } \mathrm{N}_{2}\end{array}$ & $\begin{array}{r}306 \\
64\end{array}$ & $\begin{array}{r}238 \\
62\end{array}$ & $\begin{array}{r}235 \\
53\end{array}$ & $\begin{array}{ll}257 & \\
& 59 \cdot 7\end{array}$ & $\begin{array}{r}830 \\
86\end{array}$ & $\begin{array}{r}712 \\
32\end{array}$ & $\underset{55}{250 / 10 \mathrm{hr} .}$ & $\begin{array}{ll}714 & \\
& 57 \cdot 7\end{array}$ \\
\hline $\begin{array}{l}\mathrm{NH}_{4}(\mathrm{mEq} / 24 \mathrm{hr} .) \\
\% \text { of total urea } \mathrm{N}_{2}\end{array}$ & $\begin{array}{r}5 \cdot 6 \\
14 \cdot 5\end{array}$ & $\begin{array}{r}7 \\
25\end{array}$ & $\begin{array}{r}9 \cdot 8 \\
29 \cdot 5\end{array}$ & $\begin{array}{r}7 \cdot 4 \\
23\end{array}$ & $\begin{array}{l}11 \cdot 2 \\
15 \cdot 6\end{array}$ & $\begin{array}{l}29 \cdot 4 \\
15\end{array}$ & $\begin{array}{r}3 \cdot 6 \\
11 \cdot 8\end{array}$ & $\begin{array}{r}14 \cdot 7 \\
14 \cdot 1\end{array}$ \\
\hline $\begin{array}{l}\text { Amino acid } \mathrm{N}_{2} \text { (mg./24 hr.) } \\
\% \text { of total urea } \mathrm{N}_{2}\end{array}$ & $\begin{array}{r}37 \cdot 3 \\
7 \cdot 4\end{array}$ & $\begin{array}{r}20 \\
5\end{array}$ & $\begin{array}{r}20 \cdot 4 \\
4 \cdot 4\end{array}$ & \begin{tabular}{cc|}
$28 \cdot 4$ & \\
& $6 \cdot 4$
\end{tabular} & $\begin{array}{l}43 \\
4 \cdot 5\end{array}$ & $\begin{array}{r}58 \\
2\end{array}$ & $\begin{array}{l}21 / 10 \mathrm{hr} \\
4 \cdot 6\end{array}$ & $3 \cdot 4$ \\
\hline $\begin{array}{l}\text { Creatinine } \mathrm{N}_{2}(\mathrm{mg} / / 24 \mathrm{hr} \text {.) } \\
\% \text { of total urea } \mathrm{N}_{2}\end{array}$ & $\begin{array}{l}33 \\
4 \cdot 5\end{array}$ & $\begin{array}{r}27 \\
7\end{array}$ & $\begin{array}{r}27 \\
5\end{array}$ & $5 \cdot 5$ & 377 & $\begin{array}{l}51 \\
2 \cdot 3\end{array}$ & $\underset{5}{22 / 10 \mathrm{hr}}$ & $3 \cdot 7$ \\
\hline Total & & & & $94 \cdot 6$ & & & & $78 \cdot 9$ \\
\hline
\end{tabular}

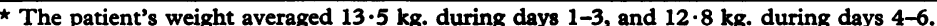

$t$ The results of the low and high protein diet are indicated by the first line: protein intake 1 g./kg. per day $1,2,3=$ low protein diet; protein intake $3 \mathrm{~g} . / \mathrm{kg}$. per day $4,5,6=$ high protein diet.

(a) Infusion of ammonium chloride. The effects on blood ammonia and plasma urea are summarized in Table III. A conspicuous increase in blood ammonia was seen 60 minutes after the start of the infusion, when the child was on a low protein diet, and after 30 minutes when she was on a higher protein diet, in spite of the lower ammonium chloride load. The amount of ammonium chloride given did not change the blood $p H$. The urea in plasma did not rise. At the end of each infusion the child became drowsy and somnolent.

With ammonium chloride $90 \mathrm{mg}$. $/ \mathrm{kg}$. there was a decrease in concentration of most amino acids after the infusion, except for glutamic acid and glutamine. This was less pronounced with the smaller loading dose.

TABLE II

Liver Enzymes ( $\mu$ mole/60 min. per g. wet liver)

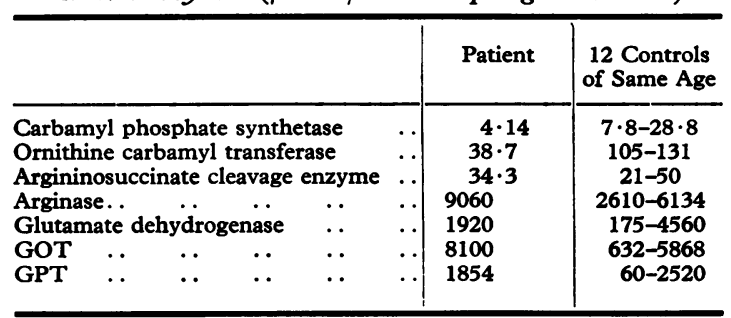

(b) Infusion of L-arginine. This amino acid was infused because of its low plasma concentration and before the results of enzyme analyses on the liver were known. The infusion led to a hyperammonaemia of long duration. After 240 minutes the ammonia concentration was still $274 \mu \mathrm{g}$. $/ 100 \mathrm{ml}$.

(c) Infusion of L-lysine. Blood ammonia decreased slightly from $74 \mu \mathrm{g}$. $/ 100 \mathrm{ml}$. to $55 \mu \mathrm{g} . / 100 \mathrm{ml}$. during the infusion.

(d) Ornithine loading test. No change in blood ammonia could be observed. The plasma level of ornithine increased faster and reached a higher level in the patient than in the control (Table IV). At the same time glutamic acid and later glutamine levels increased in the patient but not in the control. There was no significant change in arginine, citrulline, and proline levels.

Effects of low protein and high protein diet on ureogenesis. After the patient had been on a low protein diet of $0.5-1 \mathrm{~g} . / \mathrm{kg}$. per day for 5 months she was changed to a higher protein diet of $3 \mathrm{~g} . / \mathrm{kg}$. per day: on the first day on this diet she started vomiting and on the third day became comatose, when blood ammonia increased to $232 \mu \mathrm{g}$. $/ 100 \mathrm{ml}$. The effects on the metabolism of nitrogen are summarized in Table $I$. There was no change in the blood urea, while the excretion of total nitrogen, urea nitrogen, ammonia nitrogen, and amino acid nitrogen increased strikingly during the high protein diet regime. The percentage of total nitrogen excreted in the urine as urea nitrogen did not change significantly, while the percentage of total nitrogen excreted in the urine as ammonia nitrogen and amino nitrogen decreased. The percentage of 'unaccounted' nitrogen was much higher $(21 \%)$ on a high than on a low protein diet. It might have been excreted in the form of compounds not tested with the present methods.

Excretion of orotic acid in urine. Orotic acid and uridine were not detected in the urine by paper chromatography while the patient was on a low protein diet. With a chemical method the orotic aciduria varied between 6-15 mg./24 hours. When the child 
TABLE III

Effect of Amino Acid Loading Test on Blood Ammonia and Urea

\begin{tabular}{|c|c|c|c|c|c|c|}
\hline \multirow{2}{*}{ Test } & \multicolumn{3}{|c|}{ Patient } & \multicolumn{3}{|c|}{ Control } \\
\hline & Time (min.) & $\mathrm{NH}_{3}(\mu \mathrm{g} . / 100 \mathrm{ml})$. & Urea (mg./100 ml.) & Time (min.) & $\mathrm{NH}_{3}(\mu \mathrm{g} . / 100 \mathrm{ml})$. & Urea (mg./100 ml.) \\
\hline $\begin{array}{l}\mathrm{NH}_{4} \mathrm{Cl} . \\
(90 \mathrm{mg} . / \mathrm{kg} .)\end{array}$ & $\begin{array}{r}0 \\
60 \\
120 \\
210\end{array}$ & $\begin{array}{r}47 \\
375 \\
184 \\
84\end{array}$ & $\begin{array}{l}9 \cdot 6 \\
8 \cdot 6 \\
8 \cdot 6 \\
7 \cdot 2\end{array}$ & $\begin{array}{r}0 \\
60 \\
120\end{array}$ & $\begin{array}{r}40 \\
114 \\
42\end{array}$ & $\begin{array}{l}21 \\
26 \\
24\end{array}$ \\
\hline $\begin{array}{l}\mathrm{NH}_{4} \mathrm{Cl} . \\
\quad(40 \mathrm{mg} . / \mathrm{kg} .)\end{array}$ & $\begin{array}{r}0 \\
30 \\
60 \\
120 \\
180\end{array}$ & $\begin{array}{r}49 \\
283 \\
85\end{array}$ & $\begin{array}{l}14 \cdot 6 \\
14 \\
12\end{array}$ & $\begin{array}{r}0 \\
30 \\
60 \\
120\end{array}$ & $\begin{array}{r}55 \\
128 \\
50 \\
53\end{array}$ & $\begin{array}{l}14 \cdot 6 \\
15 \cdot 4 \\
14 \cdot 6 \\
15 \cdot 4\end{array}$ \\
\hline $\begin{array}{l}\text { L-lysine I.V. } \\
\text { (100 mg./kg.) }\end{array}$ & $\begin{array}{r}0 \\
60 \\
180\end{array}$ & $\begin{array}{l}74 \\
55 \\
69\end{array}$ & $\begin{array}{l}25 \\
16 \cdot 2 \\
16\end{array}$ & $\begin{array}{r}0 \\
60 \\
180\end{array}$ & $\begin{array}{l}56 \\
62 \\
44\end{array}$ & $\begin{array}{l}19 \cdot 3 \\
20 \\
20 \cdot 5\end{array}$ \\
\hline $\begin{array}{l}\text { DL-ornithine oral } \\
(200 \mathrm{mg} . / \mathrm{kg} .)\end{array}$ & $\begin{array}{r}0 \\
120 \\
180\end{array}$ & $\begin{array}{l}33 \\
67\end{array}$ & $\begin{array}{l}27 \\
20\end{array}$ & $\begin{array}{r}0 \\
60 \\
120\end{array}$ & $\begin{array}{l}56 \\
48 \\
55\end{array}$ & $\begin{array}{l}14 \cdot 6 \\
15 \cdot 4 \\
16\end{array}$ \\
\hline $\begin{array}{l}\text { L-arginine I.V. } \\
(200 \mathrm{mg} . / \mathrm{kg} .)\end{array}$ & $\begin{array}{r}0 \\
240\end{array}$ & $\begin{array}{l}154 \\
274\end{array}$ & & $\begin{array}{r}0 \\
240\end{array}$ & $\begin{array}{l}73 \\
68\end{array}$ & \\
\hline $\begin{array}{l}\text { Water } \\
\quad(2 \mathrm{ml} . / \mathrm{kg} .)\end{array}$ & $\begin{array}{r}0 \\
60 \\
180\end{array}$ & $\begin{array}{l}75 \\
71 \\
69\end{array}$ & $\begin{array}{l}21 \\
20 \\
19 \cdot 5\end{array}$ & & & \\
\hline
\end{tabular}

was comatose while on the high protein diet, the orotic aciduria increased up to $190 \mathrm{mg} . / 24$ hours.

Genetics. The mother of this child has been examined several times, including during pregnancy; her fasting and postprandial blood ammonia has always been normal. There are two other female sibs in this family who are normal with normal blood ammonia levels. Blood ammonia determinations, performed on the father, were normal.

TABLE IV

Plasma Amino Acids in $\mu$ Mole \% Before and During an Oral DL-Ornithine Loading (200 mg./kg.)

\begin{tabular}{|c|c|c|c|c|c|c|c|c|c|}
\hline & & \multicolumn{2}{|c|}{ Normal } & \multicolumn{3}{|c|}{ Patient } & \multicolumn{3}{|c|}{ Control } \\
\hline & & Mean & Deviat. & Before & $2 \mathrm{hr}$. & $4 \mathrm{hr}$. & Before & $2 \mathrm{hr}$. & $4 \mathrm{hr}$. \\
\hline 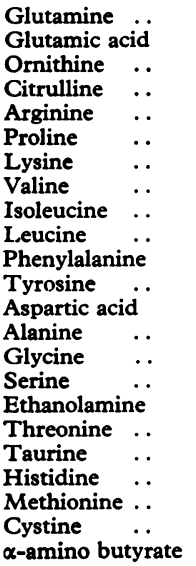 & 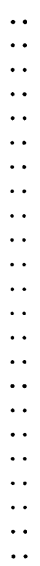 & $\begin{array}{l}43 \\
20 \\
9 \cdot 7 \\
3 \cdot 4 \\
8 \cdot 2 \\
19 \\
15 \\
23 \\
7 \cdot 2 \\
13 \cdot 9 \\
8 \\
6 \\
4 \\
37 \\
26 \cdot 8 \\
21 \cdot 4 \\
1 \cdot 4 \\
11 \\
15 \\
10 \\
2 \cdot 2 \\
3 \cdot 4 \\
2 \cdot 3\end{array}$ & $\begin{array}{l}21-58 \\
15-57 \\
4 \cdot 6-11 \\
1 \cdot 7-5 \\
2 \cdot 8-9 \cdot 9 \\
15-43 \\
9 \cdot 2-19 \\
10-33 \\
3 \cdot 4-9 \cdot 2 \\
6 \cdot 4-16 \\
3 \cdot 5-10 \\
3 \cdot 4-8 \cdot 6 \\
0 \cdot 8-7 \cdot 5 \\
18-39 \\
15-29 \\
11-20 \\
11-2 \cdot 5 \\
9-15 \\
9-24 \\
6-10 \\
1 \cdot 4-3 \cdot 7 \\
\text { trace- } 4 \cdot 5 \\
1 \cdot 1-3 \cdot 7\end{array}$ & $\begin{array}{l}46 \\
26 \cdot 5 \\
5 \cdot 6 \\
1 \cdot 7 \\
4 \cdot 7 \\
29 \cdot 4 \\
9 \\
15 \cdot 5 \\
4 \cdot 2 \\
6 \cdot 4 \\
3 \cdot 9 \\
6 \\
1 \cdot 5 \\
90 \cdot 1 \\
33 \cdot 9 \\
28 \\
0 \cdot 5 \\
10 \cdot 5 \\
5 \cdot 2 \\
8 \cdot 8 \\
3 \cdot 3 \\
0 \cdot 2 \\
1 \cdot 9\end{array}$ & $\begin{array}{l}51 \cdot 4 \\
49 \\
95 \cdot 4 \\
1 \cdot 59 \\
6 \cdot 5 \\
29 \cdot 9 \\
13 \\
16 \cdot 1 \\
4 \cdot 9 \\
6 \cdot 4 \\
4 \cdot 1 \\
8 \cdot 2 \\
3 \cdot 4 \\
77 \cdot 4 \\
28 \cdot 9 \\
31 \\
1 \cdot 1 \\
11 \cdot 2 \\
5 \cdot 9 \\
9 \cdot 1 \\
3 \cdot 3 \\
0 \cdot 5 \\
1 \cdot 6\end{array}$ & $\begin{array}{c}81 \cdot 3 \\
23 \cdot 2 \\
57 \cdot 3 \\
2 \\
7 \cdot 5 \\
30 \\
14 \\
17 \\
6 \cdot 1 \\
9 \cdot 3 \\
4 \cdot 7 \\
7 \\
2 \cdot 9 \\
61 \cdot 1 \\
22 \cdot 4 \\
7 \cdot 9 \\
1 \\
9 \cdot 8 \\
7 \cdot 4 \\
9 \cdot 5 \\
3 \cdot 6 \\
0 \cdot 7 \\
2 \cdot 4\end{array}$ & $\begin{array}{c}21 \cdot 1 \\
11 \cdot 3 \\
4 \cdot 6 \\
1 \cdot 7 \\
6 \\
42 \\
9 \cdot 5 \\
10 \cdot 4 \\
3 \cdot 5 \\
6 \cdot 4 \\
3 \cdot 9 \\
4 \cdot 5 \\
3 \cdot 8 \\
18 \cdot 2 \\
15 \cdot 2 \\
12 \cdot 6 \\
2 \cdot 6 \\
10 \cdot 9 \\
20 \cdot 8 \\
6 \cdot 5 \\
1 \cdot 7 \\
0 \cdot 5 \\
1 \cdot 6\end{array}$ & $\begin{array}{c}14 \cdot 6 \\
10 \cdot 1 \\
31 \cdot 3 \\
1 \cdot 96 \\
5 \cdot 8 \\
35 \\
9 \cdot 1 \\
9 \cdot 3 \\
3 \cdot 5 \\
5 \cdot 9 \\
4 \cdot 1 \\
4 \\
3 \cdot 3 \\
14 \\
13 \cdot 9 \\
7 \cdot 1 \\
3 \cdot 1 \\
7 \cdot 2 \\
20 \cdot 8 \\
6 \\
2 \cdot 3 \\
0 \cdot 6 \\
1 \cdot 5\end{array}$ & $\begin{array}{c}23 \cdot 2 \\
6 \cdot 9 \\
70 \cdot 1 \\
1 \cdot 97 \\
5 \cdot 1 \\
27 \\
7 \cdot 9 \\
9 \cdot 9 \\
3 \cdot 9 \\
6 \\
3 \cdot 9 \\
3 \cdot 1 \\
1 \cdot 3 \\
14 \cdot 7 \\
17 \cdot 1 \\
9 \cdot 5 \\
1 \cdot 9 \\
7 \cdot 49 \\
10 \cdot 1 \\
6 \cdot 19 \\
2 \\
0 \cdot 7 \\
1 \cdot 8\end{array}$ \\
\hline
\end{tabular}




\section{Discussion}

In this baby repeated attacks of lethargy with vomiting were associated with high levels of blood ammonia. These occurred when the amount of protein in the diet was increased, the baby remaining well while on a low protein diet. The absence of severe liver damage on liver biopsy, the normal content of lysine and glycine of the plasma, and the normal lysine tolerance test rule out secondary causes of hyperammonaemia.

Russell et al. (1962) described the first cases of hyperammonaemia; in one the activity of ornithine carbamyl transferase was depressed to $5 \%$, in the other to $10 \%$ of the lowest normal values. Several other enzymes of the urea cycle, however, also showed lower activities.

In our case, the ornithine carbamyl transferase activity was moderately reduced and amounted to $35 \%$ of the lowest value of the normal range. As in one case of Russell's, the activity of carbamyl phosphate synthetase was depressed to $50 \%$ of the lowest value of the normal range. The decrease of two enzymes of the urea cycle is difficult to explain on a genetic base. The very low activity of ornithine carbamyl transferase suggests that this defect is the more important one. As has been shown in rat experiments, urea cycle enzymes can adapt to changes in the concentration of reaction products (Schimke, 1962). It might therefore be that the accumulating carbamyl phosphate, which cannot be incorporated to form citrulline, leads to a deceleration of the carbamyl phosphate synthetase reaction. Since the other liver enzymes of the urea cycle as well as the glutamine dehydrogenase and the alanine aminotransferase were normal, liver damage can be excluded. A general decrease of the urea cycle enzymes, as observed in one case of Russell (1962), might be a sign of subclinical liver damage. In a case of anicteric subacute hepatitis in childhood with periodic ammonia intoxication, low activities of urea cycle enzymes were noted (Colombo et al., 1967b).

If the diminution of ornithine carbamyl transferase activity is the main defect, one would expect an increase in plasma ornithine and a low concentration of citrulline, and this was present when the patient was on a normal or high protein diet. On a low protein diet the over-all activity of the urea cycle may be sufficient to deal with the normal plasma level of ornithine. Since ornithine can be converted to proline and glutamic acid, it is possible that a part of ornithine is diverted into that pathway. Both the increased plasma concentration of glutamic acid on high protein intake, and the results of the ornithine loading test, suggest that if ornithine accumulates it is rapidly converted to glutamic acid.

The high concentration of glutamine in CSF and in plasma after a diet low in protein suggest that the patient apparently fixes a large amount of ammonia in the form of glutamine. Duda and Handler (1958) have shown in rats that if ${ }^{15} \mathrm{~N}$ labelled ammonia is given intravenously, 30 minutes after injection $72 \%$ of the label is present in glutamine and $18 \%$ in urea. Ammonia is therefore rapidly incorporated into the amide group of glutamine. With a defective urea cycle, this incorporation into glutamine leads to a high concentration of this substance in the body fluids. In the kidney, ammonia is split off from glutamine by the action of glutaminase, and the high ammonia content of the patient's urine while on a high protein diet is the result of this mechanism.

Carbamyl phosphate and aspartic acid may react to form orotic acid, so that carbamyl phosphate synthetase also catalyses the first step of the synthesis of pyrimidines. Accumulating ammonia which is not fixed by glutamic acid to form glutamine may be taken up in the carbamyl phosphate synthetase reaction. The accumulation of ammonia could therefore increase the rate of orotic acid excretion in the urine of the patient, especially when on a high protein intake.

When the patient is on a high protein diet she is able to increase her ureogenesis to a limited extent. However, the percentage of nitrogen excreted as urea does not increase when she is changed from a low to a high protein intake. This points to the fact that she is unable to raise the rate of urea formation adequately, in conformity with the observation of partial enzyme deficiency in the urea cycle.

The absence of symptoms in both parents and sibs, the normal blood ammonia levels in the mother, in the father, and in the sibs, the relative mildness of the condition in the child, and the moderate decrease in the ornithine carbamyl transferase (to $35 \%$ of the lowest control value), suggest that our patient suffers from the same condition as the variant type of liver transcarbamylase deficiency recently described by Levin et al. (1969).

\section{Summary}

An 18-month-old female infant, with mental retardation and repeated attacks of vomiting with lethargy or coma since birth, was shown to suffer from periodic ammonia intoxication, due to a defect in ureogenesis. Loading tests with ammonium chloride, and with ornithine produced an abnormal increase in blood ammonia, glutamic acid, and 
glutamine. Liver biopsy showed only a slight fatty degeneration of the hepatocytes, but enzyme analysis of liver biopsy tissue showed decreases in both ornithine carbamyl transferase and carbamyl phosphate synthetase.

A low protein diet prevented hyperammonaemia and allowed normal growth, but the child remained retarded.

\section{REFERENCES}

Brown, G. W., Jr., and Cohen, P. P. (1959). Comparative biochemistry of urea synthesis. I. Methods for the quantitative assay of urea cycle enzymes in liver. f. biol. Chem., 234, 1769.

Colombo, J. P., Bürgi, W., Richterich, R., and Rossi, E. (1967a). Congenital lysine intolerance with periodic ammonia intoxication: a defect in L-lysine degradation. Metabolism, 16, 910.

- and Richterich, R. (1968). Urea cycle enzymes in the developing human fetus. Enzym. biol. Clin., 9, 68.

- Ungari, S., Ferrazzini, F., Richterich, R., and Rossi, E. (1967b). Periodischer stupor und Ammoniakintoxikation bei einem Kind mit anikterischer, subakuter Hepatitis. Helv. paediat. Acta, 22, 331 .

Duda, G. D., and Handler, P. (1958). Kinetics of ammonia metabolism in vivo. 7. biol. Chem., 232, 303.

Efron, M. L. (1965). Quantitative estimation of amino acids in physiological fluids using a Technicon amino acid analyzer. In Automation in Analytical Chemistry (Technicon Symposium), Mediad, New York.

Freeman, J. M., Nicholson, J. F., Masland, W. S., Rowland, L. P., and Carter, S. (1964). Ammonia intoxication due to a congenital defect in the urea synthesis. (Abstr.) f. Pediat., 65, 1039.

Hooft, C., Carton, D., and De Schrijver, F. (1968). Arginosuccinurie. Read before the Société de Pédiatre de l'Est et du Nord, Lille.

Hopkins, I. J., Connelly, J. F., Dawson, A. G., Hird, F. J. R., and Maddison, T. G. (1969). Hyperammonaemia due to ornithine transcarbamylase deficiency. Arch. Dis. Childh., 44, 143.

Levin, B. (1965). Argininosuccinic aciduria. Read before the 11th International Congress of Pediatrics, Tokyo.
-, Abraham, J. M., Oberholzer, V. G., and Burgess, E. A. (1969a). Hyperammonaemia: a deficiency of liver ornithine transcarbamylase: occurrence in mother and child. Arch. Dis. Childh., 44, 152.

—, Dobbs, R. H., Burgess, E. A., and Palmer, T. (1969b). Hyperammonaemia. A variant type of deficiency of liver ornithine transcarbamylase. ibid., 44, 162.

McMurray, W. C., Mohyuddin, F., Bayer, S. M., and Rathbun, J. C. (1964). Citrullinuria a disorder of amino acid metabolism associated with mental retardation. Proceedings of the International Congress on the Study of Mental Retardation, p. 117. Copenhagen.

Richterich, R. (1969). Clinical Chemistry'. S. Karger and Academic Press, New York.

Rogers, L. E., and Porter, F. S. (1968). Hereditary orotic aciduria. II. A urinary screening test. Pediatrics, 42, 423.

Russell, A., Levin, B., Oberholzer, V. G., and Sinclair, L. (1962). Hyperammonaemia: a new instance of an inborn enzymatic defect of the biosynthesis of urea. Lancet, 2, 699.

Schimke, R. T. (1962). Adaptive characteristics of urea cycle enzymes in the rat. $\mathcal{f}$. biol. Chem., 237, 459.

Seligson, D., and Hirahara, K. (1957). The measurement of ammonia in whole blood, erythrocytes, and plasma. f. Lab. clin. Med., 49, 962.

Tedesco, T. A., and Mellman, W. J. (1967). Argininosuccinate synthetase activity and citrulline metabolism in cells cultured from a citrullinemic subject. Proc. nat. Acad. Sci. (Wash.), $57,829$.

Thomson, R. Y. (1960). In Chromatographic and Electrophoretic Techniques, Vol. I, p. 244. Ed. by I. Smith. Heinemann, London.

Tomlinson, S., and Westall, R. G. (1964). Argininosuccinic aciduria: argininosuccinase and arginase in human blood cells. Clin. Sci., 26, 261.

Vis, H. L. (1963). Aspects et Mécanismes des Hyperaminoaciduries de l'Enfance. Editions Arscia, Bruxelles.

Weber, H. (1963). Mikromethode zur Bestimmung der OrnithinCarbamoyl-Transferase (OCT) in Serum und Liquor. Klin. Wschr., 41, 37.

Correspondence to Dr. L. M. Corbeel, Paediatric Akademisch Ziekenhuis, St. Rafaël, Kapucienvoer, Leuven, Belgium. 